\title{
Physiological Quality of Soy Cultivar Seeds
}

\section{Beni Nzamu Iluku*, Nicolay Wolff Ruppin, Lorena Emanuelle da Mata Terra, Thaiś e Ohana Moura Fernandes, Gabriel David Mendes Queiroz, Thyago Henrique Sanguinete Souza, Delacyr da Silva Brandão Junior, Carlos Juliano Brant Albuquerque and Raphael Moreira Siqueira}

Federal University of Minas Gerais, Brazil

*Corresponding Author: Beni Nzamu Iluku, Federal University of Minas Gerais, Brazil.

DOI: 10.31080/ASAG.2020.04.0811
Received: February 12, 2020

Published: February 24, 2020

(C) All rights are reserved by Beni Nzamu Iluku., et al.

\begin{abstract}
The aim of this study was to analyze the degree of moisture (\%U), germination (\%), fresh/dry hypocotyl mass (g) and fresh/dry primary root (g) of the 24 soybean cultivars to have the most adapted cultivar in the Montes Claros region. The experimental design was completely randomized, using 4 replicates for the treatment (cultivar). It was found that the means followed by the same lower case letters do not differ statistically from each other by the Tukey test at 5\% probability. Among the cultivars evaluated, the cultivar CD2750IPRO showed greater physiological potential for all variables and cultivars CD270IPRO, AS3730IPRO, NS5959IPRO and M7739IPRO reached germination above $80 \%$, with this minimum necessary of the 24 cultivars evaluated, but none of them showed high vigor.

Keywords: Glycine max (L.) Merril; Vigor; Methodology
\end{abstract}

\section{Introduction}

Soy (Glycine max (L.) Merril.) is a fabaceae of great economic relevance in the world. One of the main aspects considered for assessing the quality of soybean seeds is the physiological attributes, since these are directly related to estimates of vigor and field performance. For the planting of soybeans it is of fundamental importance to use quality seeds to obtain uniformity, vigorous plants and therefore good productivity [1].

Thus, the present study aimed to assess the physiological quality of seeds of 24 soybean cultivars.

\section{Material and Methods}

The present study was conducted in the demonstration unit in the Seed Analysis Laboratory of the Agrarian Sciences Institute of the Federal University of Minas Gerais (Las/ICA-UFMG) Campus Montes Claros-MG.

The seeds were obtained from an experimental area of Center Studies in Cereal Production and Technology (NEProTeC) of ICA/ UFMG, where 24 cultivars were used.

The statistical procedure was completely randomized (DIC), with 4 replicates per treatment (cultivar).

In this work, the following parameters were evaluated: Degree of Moisture (\%U), Germination (\%), Fresh/Dry hypocotyl mass (g) and Fresh/Dry primary root $(\mathrm{g})$.

\section{Results and Discussion}

\begin{tabular}{|l|c|c|c|c|}
\hline Cultivars & $\begin{array}{c}\text { Moisture } \\
\mathbf{( \% )}\end{array}$ & $\begin{array}{c}\text { Germination } \\
\mathbf{( \% )}\end{array}$ & $\begin{array}{c}\text { Fresh hypocotyl mass } \\
\text { and root } \mathbf{1}^{\mathbf{a}} \mathbf{( g )}\end{array}$ & $\begin{array}{c}\text { Dry mass of the hypocotyl } \\
\text { and root } \mathbf{1}^{\mathbf{a}} \mathbf{( g )}\end{array}$ \\
\hline 99R09 & 6,35 & 13 & 0,44575 & 0,03605 \\
\hline AS3610IPRO & 6,97 & 62 & 3,06225 & 0,25455 \\
\hline AS3730IPRO & 6,62 & 86 & 5,24450 & 0,42715 \\
\hline BMX Ponta IPRO & 6,46 & 68 & 4,39900 & 0,30228 \\
\hline CD2720IPRO & 6,48 & 73 & 5,00950 & 0,37233 \\
\hline CD2728IPRO & 4,71 & 57 & 3,62425 & 0,26845 \\
\hline
\end{tabular}


Physiological Quality of Soy Cultivar Seeds

\begin{tabular}{|l|l|l|l|l|}
\hline CD2730IPR0 & 6,55 & 71 & 4,00630 & 0,29608 \\
\hline CD2750IPR0 & 6,44 & 89 & 5,64000 & 0,44255 \\
\hline CD2817IPR0 & 6,49 & 23 & 0,93450 & 0,08315 \\
\hline DM6563RSFIPR0 & 6,67 & 63 & 4,42125 & 0,30125 \\
\hline DS5916IPR0 & 6,83 & 72 & 4,83550 & 0,29865 \\
\hline M6210IPR0 & 6,93 & 20 & 0,84975 & 0,07553 \\
\hline M7110IPR0 & 6,6 & 38 & 1,43200 & 0,11255 \\
\hline M7739IPR0 & 6,48 & 81 & 5,48475 & 0,38535 \\
\hline M8210IPR0 & 6,59 & 52 & 2,14825 & 0,17735 \\
\hline NA5909RG & 6,48 & 79 & 4,63900 & 0,35565 \\
\hline NS5959IPR0 & 6,95 & 84 & 5,22500 & 0,41463 \\
\hline NS6906IPR0 & 6,59 & 75 & 4,20450 & 0,30513 \\
\hline NS6909IPR0 & 6,68 & 77 & 4,14775 & 0,33305 \\
\hline NS7300IPR0 & 6,82 & 67 & 4,18613 & 0,31433 \\
\hline NS7338IPR0 & 6,69 & 30 & 0,88725 & 0,08408 \\
\hline TMG7062IPR0 & 6,69 & 70 & 3,98950 & 0,30055 \\
\hline RK6813 & 6,86 & 65 & 3,97975 & 0,27068 \\
\hline RK7814 & 6,91 & 58 & 3,66900 & 0,02572 \\
\hline
\end{tabular}

Table

Notes: The averages followed by the same lower case letters do not differ statistically from each other by the Tukey test at $5 \%$ probability.

\section{Conclusion}

- $\quad$ Among the cultivars evaluated, the cultivar CD2750IPRO showed greater physiological potential for all variables.

- $\quad$ The cultivars CD2750IPRO, AS3730IPRO, NS5959IPRO and M7739IPRO reached germination above $80 \%$, this minimum being necessary of the 24 cultivars evaluated, but none of them have high vigor.

\section{Bibliography}

1. BRASIL. Ministério da Agricultura, Pecuária e Abastecimento. "Regras para aná lise de sementes/Ministério da Agricultura, Pecuá ria e Abastecimento". Secretaria de Defesa Agropecuá ria. Brasília: Mapa/ACS (2009): 399.

\section{Assets from publication with us}

- Prompt Acknowledgement after receiving the article

- Thorough Double blinded peer review

- Rapid Publication

- Issue of Publication Certificate

- High visibility of your Published work

Website: www.actascientific.com/

Submit Article: www.actascientific.com/submission.php Email us: editor@actascientific.com

Contact us: +919182824667 